\title{
Behind Our Sip of Tea: An Ecofeminist Study of Environmental Refugees in Kokilam Subbiah's Mirage
}

\author{
R. K. SANGEETHA \\ Department of English, \\ B.S. Abdur Rahman Crescent Institute of Science and Technology, \\ Vandalur, Chennai, India. \\ rkgeetha1990@gmail.com \\ P. RATHNA \\ Department of English, \\ B.S. Abdur Rahman Crescent Institute of Science and Technology, \\ Vandalur, Chennai, India.
}

\begin{abstract}
Women, in general, have been victims of so many oppressive factors such as domestic violence, gender inequalities, and patriarchal oppression in all the contexts such as personal, social, cultural, and professional. Furthermore, they often bear the brunt of natural calamities such as tsunami, famine, drought, wildfire, and hurricane and manmade disasters like war, industrialisation, urbanisation and so on, when compared to men. Many ecofeminists and researchers have studied the homogeneity between women and nature, similarity in their traits, their subjugation by the oppressive powers, and their resultant plight, under various discriminative factors such as race, caste, class, religion, culture, and colonialism. This paper aims to explore the additional challenges faced by women refugees, in particular, climate refugees as portrayed in Kokilam Subbiah's Mirage, through the lens of ecofeminism. Throughout the novel, Kokilam Subbiah has captured the lives of women refugees through the metaphorical representation of nature. This study also attempts to underscore the parallelism between the refugee women and nature and how they are closely intertwined with each other in their victimisation and resilience and endeavours to study the veracity and universality of Warren's premise of "naturalizing women" and "feminizing nature" with reference to the novel Mirage.
\end{abstract}

Keywords: climate refugees; naturalising women; feminising nature; patriarchy; women refugees

\section{INTRODUCTION}

The exponential increase in the number of climate refugees across the globe mandates serious attention and urgent action. Norman Myers, who has written a lot about climate change and resultant migration, considers "climate and environmental migration as one of the most important humanitarian crises of our time... In 1993 he predicted that rises in temperature worldwide would by the year 2050 result in an increase in the number of environmental refugees to 150 million, a figure which in 2002 he revised upwards to 200 million" (qtd. Maretti et al., 2019, p. 146). Thus, there is an exigency to study the predicament of these refugees and their intrinsic problems in order to effectuate appropriate therapeutic intervention.

An environmental refugee is a person displaced due to environmental factors such as increased droughts, desertification, sea-level rise, and disruption of seasonal weather patterns. These adverse changes in the environment jeopardise the well-being or secured livelihood of the people, especially, the poor. As observed by Bates, "Natural disasters are differentiated from other disasters because of a significant difference in origin. These disasters include hurricanes, floods, tornadoes, earthquakes or any other weather or geological event that renders a place previously inhabited by humans unfit for habitation, either permanently or temporarily" (2002, p.471). Consequently, climate refugees may choose to flee or migrate to another country, or they may migrate internally within their own country. 
Environmental refugees are denoted through different terms such as environmental migrants, climate refugees, and environmentally displaced persons. El-Hinnawi defines the term as follows:

\begin{abstract}
Environmental refugees are defined as those people who have been forced to leave their traditional habitat, temporarily or permanently, because of a marked environmental disruption (natural and/or triggered by people) that jeopardized their existence and/or seriously affected the quality of their life. By 'environmental disruption' in this definition are meant any physical, chemical and/or biological changes in the ecosystem (or the resource base) that render it, temporarily or permanently, unsuitable to support human life.
\end{abstract}

(qtd. Sunani. 2017, p. 19)

Women are the victims of so many oppressive factors such as domestic violence, gender inequalities, and patriarchal oppression. Furthermore, they bear the brunt of natural calamities such as tsunami, famine, drought, wildfire, and hurricane and manmade disasters like war, industrialisation, urbanisation and so on, when compared to men. Ecofeminism represents that the exploitation of nature and the domination of women are intimately connected with the perception of race, class, caste, and colonialism. Many ecofeminists and researchers have studied the subjugation and exploitation of women and nature, homogeneity in the traits manifested by them and similarity in the plight of women and nature under various contexts mentioned above, such as race, class, caste, and so on. This present study endeavours to explore the additional challenges, that is, apart from the challenges faced by women in general, faced by women refugees, in particular, climate refugees as presented by Kokilam Subbiah in her novel, Mirage. This novel talks about the plight of environmental refugees from Tamil Nadu who migrate to Sri Lanka in search of livelihood which they lost due to famine and drought in their native place. In this novel also, women prove to be more vulnerable than men to the disastrous impacts of environmental calamities.

This study has been framed on the following questions: What are the implications of environmental disasters? How is the interconnectedness between nature and women refugees represented in Mirage? How do women refugees and nature become more vulnerable in the hands of power structures? How do they weather the storm? What is the heart-rending story of women refugees behind our sip of tea? In this research, an attempt has been made to study the predicament of women refugees from Tamil Nadu, their hopes, their challenges, trials and tribulations, their fortitude and resilience as portrayed in Kokilam Subbiah's Mirage through the lens of ecofeminism. This study also attempts to find out how Kokilam Subbiah establishes the parallelism between women refugees and nature and how they are closely intertwined with each other by using Nature as a trope. In addition, it examines the veracity and universality of Warren's premise of "naturalizing women" and "feminizing nature" with reference to the novel Mirage.

\title{
THEORETICAL BACKGROUND
}

The gravity of the issues related to climate change and the alarming rise in the number of environmental refugees, consequent to the climate change induced environmental disorders have been some of the emerging themes in contemporary literature and literary studies across the globe. The greater parts of research and discussion on climate changes in literature have been done under the broad grouping of ecocriticism. According to Slovic, Ecocriticism is "the study of explicit environmental texts by way of any scholarly approach, or conversely, the scrutiny of ecological implications and human- nature relationship in any literary text, even texts that seem, at first glance, obvious of the nonhuman world" (qtd. Ahmed \& Hashim, 2015, p.13). Gaard in her essay "Ecofeminism and Climate Change" (2015) examines both liberal and cultural ecofeminist perspectives, highlighting how women have been kept out of climate change policy discussions while being disproportionately affected by its consequences. Tan 
(2021) examines J.G. Ballard's work of climate fiction, The Drowned World from a social ecofeminist viewpoint, with the goal of exposing the connection between patriarchal capitalism and the oppression of women and the environment. Ecocriticism with its wide vista of diverse disciplines enables the researchers to investigate the global environmental crisis through the intersections of literature, culture, and the socio-political and the physical environment.

The term Ecofeminism, an offshoot of ecocriticism, was coined by the French writer, Francoise d' Eaubonne in 1974. Ecofeminism examines the political, historical, social, conceptual and epistemological links between the domination and destruction of women and nature. It also connects all kinds of domination such as sexism, racism, and classism, with the destruction and exploitation of environmental entities and ecosystems. As rightly observed by Kings (2017), "For more than thirty years, ecofeminism has been taking into account the interconnected nature of social categories such as gender, race, class, sexuality, caste, species, religion, nationality, dis/ability, and issues such as colonialism. It has also challenged anthropocentric modes of thought, by incorporating both species and the natural environment into the ongoing debate concerning the workings of social categorization and identity construction" (p.72). King (1989) also affirms, "[Ecofeminism's] challenge of social domination extends beyond sex to social domination of all kinds, because the domination of sex, race, and class and the domination of nature are mutually reinforcing" (p.20). Alvi et al., also assert that "It examines the hierarchical gendered relationships sketching a connection between the exploitation and degradation of the natural world and the subordination and oppression of women" (2019, p.329).

Warren and Cady (1994) emphasise the need for ecofeminist study to understand the real impact of the discrimination of women and nature. According to them, "A feminist perspective - especially an ecofeminist perspective that focuses on the interrelationships between the treatment of women and other subdominants, on the one hand, and the treatment of the nonhuman natural environment, on the other hand - shows how and where such effects will be borne disproportionately by women, children, racial minorities, and the poor" (p.7-8). Warren emphasises on the strong link between the study of nature and women thus: "According to ecofeminists, trees, water, animals, toxics, and nature language are feminist issues because understanding them helps one understand the status and plight of women cross-culturally" (2014, p.4). Thus, the present research gains significance in attempting to study the plight of environmental refugees, in particular, the women refugees, in the late nineteenth century and the beginning of the twentieth century through the lens of ecofeminism in order to effectively negotiate and tackle this ever-increasing crisis of environmental displacement.

\section{DISCUSSION}

The British Empire's indentured labour system was formed as a new type of labour acquisition for the colonies throughout the nineteenth and the early twentieth centuries. Plantation production started in Sri Lanka under British colonial control in the early nineteenth century. In order to reduce their labour expenses, the planters hired employees from the Madras Presidency in South India, where a significant number of people had been impacted by the region's chronic hunger and poverty. Women were recruited by planters from the famine-prone areas of the Madras Presidency in South India beginning in the 1830s. These women belonged to the village's lowest classes and castes, and like their male counterparts, they suffered from chronic indebtedness and wanted some type of recompense for their survival (Kurian \& Jayawardena, 2013). Against this historical backdrop, the novel Mirage resonates the causality of climate change, hunger, poverty, displacement and the resultant changes and the challenges in these migrant people's lives in the late nineteenth and the early twentieth centuries. 
According to Bruyn, "One of the ways in which climate change manifests itself in contemporary culture, and contemporary culture shapes our understanding of climate change, is through real and imagined stories of human relocation" (2020, p.1). The novel, Mirage was first published in Tamil as Thoorathu Pachai in 1964 by Kokilam Subbiah and was translated into English by the author in 2006. Subbiah was involved in unionising Tamil labourers in Sri Lanka. Her novel, Mirage renders the history of migrants from an Indian state, Tamil Nadu to Sri Lanka due to severe drought and famine during the last few years of the nineteenth century and the early twentieth century. Mirage is an unending narration of economic and sexual abuse, frustration, and the struggle for survival. This novel unravels the ordeals of the poor peasants during the drought and the obstinate indifference of mirasdars (rich landlords) towards their distress and elucidates the causative factors for their migration. It deals with the lives of four generations of Indian women and their families as refugees in Sri Lanka. The author and translator, Subbiah states in the preface, "This book is an attempt to bring to the fore the unchronicled, unvoiced lives of the indentured labourers from India working on the plantations of Sri Lanka - in that sense, it is social history in the form of fiction" (Mirage ix). The appalling narratives depicted in this novel are, in fact, real-life incidents that are collected by the author from the plantation workers. This novel roughly speaks about the two world wars and the instigation of the trade union movement in the first half of the twentieth century.

In Mirage, Subbiah vividly portrays the vicious manifestations of famine and drought and the resultant pangs of poverty, hunger, and exploitation through the life of Valli, daughter of Velan and his second wife Muthamma. The novel begins when Valli was seven years old and spans approximately over a time period of half a century till Valli becomes old with grown up grandchildren. The trajectory of these women refugees' lives, caught between oppressive socio-cultural factors and environmental disasters is painted through the different stages of Valli's life as daughter, wife, daughter-in-law, mother, grandmother, and a refugee labourer. Through the women characters in the novel, the author delineates the invisible and the intricate bond between nature and women in multiple dimensions such as, a mentor and mentee respectively, as mother and daughter caring for and nourishing each other and as intimate friends offering mutual comfort and solace in their victimisation.

\section{IMPLICATIONS OF ENVIRONMENTAL DISASTERS}

Subbiah captures with precision the drought-affected, poverty-stricken wretched lives of the people, especially the women of Senthur village in Tamil Nadu. Not only the human beings, but also the flora, fauna, and the environment as a whole get affected due to this drought. There is no sign of greenery anywhere. "The animals grazed around hoping at least to find some straw... The pond in the village had dried up a long time ago. Fish in the pond were also long gone" (2009, p.3-4). The severity of the drought can be perceived through the following lines: "The goats and cattle had pulled out even the roots in their quest for food. Now they had nothing to graze on. Heat and hunger took its toll and many fell dead along the fields" (p.4). The gruesome picture of starvation and death is brought out thus:

Senthur and the villages surrounding it had been affected by drought and famine... Who could endure a drought for over three years? Hunger and starvation preyed upon the village. Many just perished in the heat. Instead of the golden-eared grain swaying in the wind, there were only the skeletons of dead animals, left by the feasting vultures.

Similar to the Mother Earth starving without rain, Muthamma, wife of Velan, is too emaciated to feed her baby because of hunger: "The baby, hoping to draw some milk from her 
breasts, sucked and dragged, only to find that there was no milk. It began to wail" (pp. 18-19). The brutality of famine is revealed when a mother dies of starvation after her childbirth. The cow, upon which the child depended on milk after the mother's death, too dies of starvation. "Now there's no milk for the baby. They are giving her ragi kanji. They say even that does not agree with the child's stomach" (pp. 10-11). Thus, the villagers' livelihood deteriorates further because of the loss of their animal wealth. Hunger and poverty make their life miserable. They become despondent and dejected, having lost all their hard-earned properties in order to alleviate their families' hunger. Valli's father Velan also has sold all of his possessions which he had before the famine, such as goats, bullocks, and a buffalo. He also loses half an acre of land to the mirasdar (a rich landlord) to pay the interest for his debts. The unfortunate situation of Senthur village people and their string of bad luck are exploited by the kangany (supervisor) who recruits them to work in a tea estate in Sri Lanka. The honey coated words of Karuppiah kangany gives them some hope about their bleak future.

The villagers who are desperate to make both ends meet and more essentially, to rid their family of starvation, take the drastic decision to leave their native place and migrate to Sri Lanka. Migration becomes Hobson's choice for them. Velan is one among the villagers who decide to migrate with his family. Velan's first wife, Sellatha, refuses to come with him to Kandy. So, he decides to take only his second wife, Muthamma and her children with him. Thus it is discernible that only the poor people are the most affected by the environmental disasters which prove to be a death knell for their normal everyday life. Their entire life and livelihood undergo complete and irreversible transformation, and for many of them, it is not for better but for worse.

\section{WOMEN REFUGEES AND THEIR ADDITIONAL CHALLENGES}

Environmental disasters affect women more than men. As asserted by Gaard that, "Women are indeed the ones most severely affected by climate change and natural disasters, but their vulnerability is not innate; rather it is a result of inequalities produced through gendered social roles, discrimination, and poverty..." $(2015$, p. 23$)$, men refugees in this novel are mostly portrayed as drunkards and they manifest their reckless attitude towards their family and women. Like Sivakami's husband, Ramasamy who propitiates his wife to the kangany (supervisor) and the dorai (White Man) for money, Valli's husband, Sengamalai also proves to be a testimony for this heedless behaviour. "Sengamalai went to the toddy tavern often and had become a habitual drinker. He took the vegetables from the garden and sold them in the village to pay for his drink" (p. 122). He even takes away the wages of Valli. Almost all the women refugees in the novel are victims of either sexual exploitation or domestic violence or both.

Women subsist in the lowest rung of the dominance hierarchy, and they remain in the last position of the pecking order with their own men and women such as husband and motherin-law respectively at home and other socially and economically powerful men at their workplace who demand and mandate total submission from them. In addition to the challenges faced by women in general, such as domestic violence, these refugee women are victims of more complex issues consequent to environmental disasters and displacement. Their journey to Hamilton Estate is excruciating for them, during which they undergo physically and mentally traumatic experiences. They are transported like animals under inhuman conditions: "The people were stuffed in the ship like tamarind pulp" (p. 27). With lack of food, sanitation and hygiene, they become emaciated. A child is dragged into the ocean when it tries to put its head out. Valli, the little girl, faints due to lack of food and water. Muthamma's baby, Papathi dies on the way due to diarrhea. "Muthamma, drained of energy and emotions, sat frozen like a 
stone" (p. 29). However, Muthamma feels that it is better that the baby died than to experience the cruelties of life in an alien land.

The women refugees as plantation workers are the easy victims of harassment and sexual exploitation by the socially powerful and influential men. Muthamma is worried about her daughter Valli's life. She decides to get her married at the earliest to safeguard her from sexual abuse: “... it would be difficult to guard our daughter amongst these wolves' (p. 70). Though marriage serves as a protective shield for Valli against sexual harassment to a certain extent, it makes her the victim of domestic violence. Valli gets married to Sengamalai. Her marriage life endows her with multiple roles to play such as a wife, daughter-in-law, mother, and grand- mother at Rasikollai Rasa Estate. She has to work in the estate during the daytime, and in the evening she has to take care of her husband's brothers and sisters who are all kids, in addition to her five children. After returning from work, she has to cook, serve food and do cleaning for the family. She gets only the leftover food, and sometimes even that becomes a rarity. Her last position in the pecking order makes it difficult to feed the baby. "Hunger can be a terrible thing, especially when you have to feed a baby" (p. 92). Every day she is harassed by her parents-in-law. Valli's mother-in-law always ill treats her and expects her to do all the household chores after her work at the plantation: "What are you doing? Can't you go early and fetch water? Have I got to tell you this every day? When are you going to cook the rice?"(p. 85). When Valli replies thus, "I just came back from work. How can I do all this work? My legs are paining" (p.85), she is beaten by her mother-her-law. "Valli, crying all the way, went with the water pot to fetch water. She sits there till it is dark and cries her heart out. The gurgling river drowned her sobs" (p. 86). She finds some solace in Mother Nature and gets rejuvenated to continue with her dreary routine. "Often she sat by the riverbank, the only place she had some peace and solitude and cried to herself" (p. 92). Thus, Mother Nature and women prove to be silent companions who comfort and nourish each other.

Valli goes to work even in heavy rain in order to avoid her mother-in-law's harassment. She used to apply tobacco on her legs to keep leeches away from her: "She knew this would not be effective for long, for the rain would wash the tobacco away" (p. 86). Metaphorically, the leeches stand for her parents-in-law. Valli knows very well that she could escape from their persecution only till evening. Added to her woes, like her mother Muthamma, Valli also loses her baby when she falls down while working in the rain. Their history of victimisation and their agonising predicament continues over the generations. The situation becomes worse when Valli is denied permission even to attend her mother Muthamma's funeral. "She cried, begged and pleaded, to at least be permitted to see her mother's final remains. But even this was denied to her" (p. 89).

Even marriage fails to give complete protection from sexual harassment to the women refugees. Like her mother Muthamma, Valli also encounters this by sinna kangany (sinna younger, kangany- supervisor). Knowing very well about the history of harassment, Valli is extremely worried about her daughter Meenakshi. She is against the idea of allowing her daughter to work in the estate for the fear of sexual exploitation rampant in the plantation. So, she decides that her daughter can work in the plantation after her marriage. Valli's another daughter Anjalai was betrayed by her husband Manikkam, who indulges in extra-marital relationship with his aunt's daughter. Valli has to take care of Anjalai's children also. Anjalai was sexually harassed by the sinna dorai, Maclean. Anjalai becomes pregnant. Valli grieves over Anjalai, "Was it only hunger and need to feed her children that had made Anjalai sell herself? Or was she raped by the demons on the estate, because she could not escape from their clutches? What will the world say? A woman without a husband, now pregnant - how was this to be explained? It was nothing new on the estate" (p. 171). Thus, these women refugees fall prey to the molestation and sexual exploitation which seem to be all pervasive and inevitable. 


\section{INTERCONNECTEDNESS WITH NATURE}

Women are closely interconnected with nature more than men. Ahmed attests that "Women's inclination to nature is not quite the same as other human's feeling. Women, as female characters, have a cozy association with nature on account of nature's gentility; for sure, women are nearer to nature than men" (2019, p. 1002). Throughout the novel, Subbiah presents the lives of women refugees through the metaphorical representation of nature. Nature is so ubiquitously presented in the novel that Nature also seems to be a protagonist like Valli, in its victimisation and its resilience. The lives of the poor villagers, especially the women, are so inextricably intertwined with Nature that their everyday life begins and ends with the guidance and support of nature. They perceive nature as a part and parcel of their life and draw meaning for every event in their life from nature. In other words, the villagers see Nature as the deciding authority of their life and they strongly believe that their destiny is entangled with Nature.

As Shiva (2010) avers, "The nature of Nature as Prakriti is activity and diversity. Nature symbols from every realm of nature are in a sense signed with the image of Nature. Prakriti lives in stone or tree, pool, fruit or animal, and is identified with them" (p.39). In Mirage, natural symbols signify the predicament of these destitute people and portend about their future. The kangany plans for the journey to Kandy in Sri Lanka on a pournami day (full moon day). According to Senthur village people, the 'Pournami day' is a symbol of new life. However, the villagers do not realise at that time that after a full moon day, a no moon day comes. The journey started by them on a full moon day wanes into a dark no moon day permanently. When they are busy preparing for their arduous journey the previous night, "The shrill cry of a jackal rented the night air and broke the noisy gossip of the cheri" (p. 14). The cry of jackal appears to be a forewarning about the miserable future awaiting Senthur village women in Sri Lanka. When they are about to leave the village in the morning, Valli is astonished by seeing the bright, red sky and asks her father, "'Appu, Appu! Look there! Look there, can you see the sky all red? What is it? Is it blood that you see there?' Valli asks in wonder... 'That child, is the sign of dawn,' replied Velan" (p. 15). Subbiah brilliantly uses the natural symbols thus:

On that momentous day too, the sun rose in the east. As usual, it spread its intense heat on the world, scorching it, as if it was angry with it. It was the day of pournami. Even though the sun has risen as usual in the eastern sky, for some in Senthur village, the sunlight had acquired an added glow. There was a pervasive love and affection for all things and beings. They looked at everything with new eyes.

Thus, the villagers are hopeful of a better life and the sign of dawn boosts their confidence and makes them optimistic about their future.

But very soon, they realise that their hope for better life is just a mirage. During their excruciatingly painful voyage, the people are wedged between fear and hopelessness, the rain and the cold, hunger and thirst, and the captain and the kangany. "It drizzled incessantly. The midday heat was brought down by the swirling wind. The angry waves rose higher and higher, dashing against the ship, drenching the people in it. The ship tossed about, like a staggering drunkard" (p. 28). Velan is very much distraught about life and his angst is visibly presented: "He gazed at the sea with its restless waves crashing against the shore. It reminded him of the futility of his own life. He felt powerless against the strong tides of fate" (p. 30). After this long and enervating journey, the refugees reach their final destination, the Hamilton Estate. "As they climbed higher, it got bitterly cold and the wind pierced their half-naked bodies like sharp needles. The gravel on the pathway pierced their soles, making them bleed. As they reached the summit they could see nothing, for the mist covered the whole place like a white sheet" (p.32). The uncertain and unpredictable future of the refugees and the impending hardships 
they need to face are powerfully implied through this natural trope. Thus, as precisely pointed out, "The environmental texture which we live in plays crucially important and inevitable roles in our physical and emotional patterns that determine our thoughts of who we are" (Hooti and Ashrafian, 2014, p. 32).

Above all, the very title of the novel Mirage serves as a metaphor in portraying the kind of life lived by these poor women before and after displacement. Their impoverished life during the famine and drought makes them victims of environmental disorders. In search of a better livelihood, they decide to migrate, which upends their life drastically in an alien land. Despite this bold venture, their hope for a better life remains to be a mirage throughout.

\section{NATURE AND WOMEN AS VICTIMS}

"Ecofeminists and ecocritical theorists have identified a striking homogeneity and a strong affinity between women and nature based on various factors such as physiological features of women, social and cultural practices forced upon them over the generations, and the male/science domination over women/nature." (Rathna, 2020, p. 484). Subbiah's Mirage manifests this parallelism between nature and women distinctively. The entire novel substantiates that the refugee women and nature are similar in their traits in preserving and sustaining life. Besides this intrinsic quality to nurture and preserve, they also display stoic endurance when they are exploited by adverse external forces. Muthamma's fortitude in tackling the kanakapillai's (accountant) sexual harassment is a case in point. She does not disclose about his misbehavior to anyone in her family for fear of confrontation and losing job. She buries it inside her, and it is to be noted that she draws the courage to tackle this kind of harassment only from nature: Muthamma dismissively said, 'There will always be plenty of leeches in the wet grass' (p.40). Kanakapillai takes his revenge on Muthamma for her refusal to yield to his wishes, by not giving rice at the store on the pretext that her family has debts to pay. Though Muthamma knows the reason for Kanakapillai's resentment towards them, she is unable to tell the truth to anyone. Even in the workplace, he indirectly targets and tortures her. Though the supervisor and the accountant are working under the white men, they behave as if they are the owners of the tea estate before the workers. They exercise their authority whenever they get the chance:

'Muthamma, your work seems to slacken day by day. If you don't do your work properly, what do you think we should do?' derided the kanakapillai, in a loud voice, for everyone to hear. 'From now on I will do as you say, ayya,' she said meekly... She had her family and children to think of, she had to give in gracefully. She hated the disgusting, hateful life she was forced to lead. She hopelessly searched for a way out, but her efforts were in vain. Muthamma was not the only one. All the labourers in the plantation shared a similar plight.

(pp. 41-42)

Analysing the homogeneity between women and nature, Warren (2014) explores "Sexist - Naturist Language." She rightly avers,

Women are described in animal terms as pets, cows, sows, foxes, chicks, serpents, bitches, beavers...
Animalizing or naturalizing women in a (patriarchal) culture where animals are seen as inferior to humans
(men) thereby reinforces and authorizes women's inferior status. Similarly, language which feminizes nature
in a (patriarchal) culture where women are viewed as subordinate and inferior reinforces and authorizes the
domination of nature: "Mother Nature" is raped, mastered, conquered, mined; her secrets are "penetrated"
and her "womb" is to be put into service of the "man of science." Virgin timber is felled, cut down; fertile
soil is tilled, and land that lies "fallow" is "barren," useless. The exploitation of nature and animals is justified
by feminizing them; the exploitation of women is justified by naturalizing them. 
The everyday life of women refugees in Mirage gives ample proof for the premise of naturalising women and feminising nature. Mother Nature has always been portrayed in the feminine context; women are ever well connected with Mother Nature and so they tend to resemble the life of Mother Nature herself. The girls in the tea estate are compared with tea saplings and the growth of the girls is compared with matured tea bushes: "The tea saplings that had been planted by the labourers, were now mature bushes, ready for picking. Those who had come to the garden as small girls were now young women, in the flush of youth. Valli too was one among them" (p. 69). While plucking the tender tea leaves, Kaveri and other women gossip about the kangany's quarrel with his wife, Poongavanam. Kaveri starts teasing Valli about the lustful eyes of the sinna kangany. Kaveri shares sinna kangany's remarks about Valli's youthful appearance: "Valli is like the tender tea leaves in her basket" (p.108). Likewise, the sinna kangany compares the bush with women's tresses. "The lush bushes now stood bare, like a woman shorn off her beautiful tresses" (p. 112).

Mirage is replete with instances where the women are abused in animal terms. Women in the tea estate are sexually harassed by the kanakapillai (accountant), kangany (supervisor) and dorai (White Man). Sivakami, the neighbor of Muthamma, is one of the victims who encounter the harassment in the tea estate. Sivakami's husband, Ramasamy who is selfish and greedy, tacitly allows her to yield to the lust of kangany and dorai for the sake of money and other benefits. He is unmindful of Sivakami's emotions or feelings. Sivakami shares her pathetic situation to Mookan, "What can I do? That fellow is harassing me, he says he will kill me...My husband is only interested in the money, he does not care how he gets it,' said Sivakami, her voice laced with sadness and despair" (p. 62). So against her wish, she has to concede to her husband's scheming. Once, when Sivakami fiercely expresses her reluctance to kangany's lustful advances, he arrogantly shouts at her, "You ass, you know you can live like a queen. You better come with me if you know what is good for you,' (p. 66). Velan and Mookan also have lustful eyes on Sivakami and they sarcastically comment about Sivakami's life and her appearance, comparing her with the wild animal, boar. "Looks like our Queen Sivakami rules,' he said mockingly... In our next birth we would be lucky to have a life like hers. Look at this boar. Isn't she a beauty!" (p. 37). Similarly, when Muthamma shouts at kanakapillai for his misbehaviour, he humiliates her: "Look at her! She talks as if she is the goddess of chastity. She looks like a harmless kitten, but there is no end to her loud mouth. Serves me right for trying to help a bitch like you. You trash! You don't realize who you are talking to!"” (p. 41). Thus, abusing women by calling them in animal terms is casually practiced by men. They always try to assert their superiority by naturalising and animalising women and deem total submission and unquestioning surrender of women as their privilege.

As Warren rightly observed, feminising nature endorses the powerful and the affluent to exploit it. In Mirage, Subbiah unravels the victimisation of nature in the hands of socially and culturally dominant men, similar to the maltreatment meted out to the women. During the journey to Hamilton Estate, many of the poor villagers die due to starvation and dehydration. When a man dies of dehydration, his corpse is thrown into the ocean. Thus, the rich and powerful take nature for granted and pollute the ocean by tossing the corpses into it. In the Hamilton Estate, forests are overexploited for tea and coffee production, and the jungles are gradually changed as Hamilton Estate's property. The refugees admire the lush appearance of the estate when they step into it: “...on one side was the virgin forest, and that the other side had been cleared and coffee bushes were planted neatly in rows" (p. 32). In fact, the "virgin forest' will become a tea or coffee estate in the near or distant future: "The jungles were cut down to make way for tea and coffee plantations" (p. 36). Similar to the sexual exploitation of the poor and destitute women refugees, nature also becomes a victim of human greed and callousness and undergoes all kinds of exploitation. 
Thus, Mirage testifies to the premise that naturalising women and feminising nature justify their exploitation and victimisation. The life of women refugees validates that like nature/land is considered as a property (material wealth), women are also considered as properties (human wealth) to be conquered and used/abused. They are treated not as a human with six senses but as inanimate objects or entities with less senses.

\section{NATURE AND WOMEN AS WARRIORS}

Women and nature display close resemblance to each other not only in their victimisation, but also in their response to their exploitation. Women seem to endure oppression or handle adverse situations in the same way, as Mother Nature does. When Mother Nature gets wellnourished, she over-joys and gives back abundantly for the prosperity and well-being of all the lives. When she gets exploited, she endures it to the maximum. However, when it goes beyond her tolerance, when she is over exploited, she acts adversely and destroys everything. Similarly, women feel happy when they are well treated. Though they are exploited and suppressed, they accept it for the sake of their family. But when it goes to the extreme of losing their self-dignity, they burst out and do not hesitate to fight against injustice. When kangany makes lecherous advances towards Sivakami, she is outraged, "'Thoo,' she spat at him. 'have you no shame? I said I do not wish to come, you better get away from here!” (p. 66). Similarly, when the kanakapillai approaches Muthamma with lust, she bursts out in anger: "come on Muthamma, I see you having a hard time with your children and your ill health and I thought I could help you out. Give you some money, maybe,' he said... 'Get away from here!' she said, raising her hoe threateningly" (p. 41)

In Mirage, the life of refugee women in the plantation is an everyday battle. Despite their hardships in the family and in the plantation, they exhibit tremendous resilience. Similar to the nature of Nature which constantly revives, renews and resuscitates, these women also continue their fight with renewed energy and hope: "The women continued picking diligently with their calloused hands, stained with the juice of tea leaves. Their fingers were nimble and quick, as they skillfully picked the two leaves and bud. They bent, leaned, straightened, and stretched themselves as they went about their business, swiftly filling their baskets with leaves" (p. 111). Unlike the men in the novel who adjust to the slavish life of the plantation, women like Valli and Deivanai want their children to get empowered through education. They hope against hope to get them rid of this slavery.

These women, in many circumstances, prove that they are self reliant, and never want to be dependent on anyone. Whether they are widows, single parents, divorcees, or betrayed by their husbands, they never lose their heart and give up their battles. Valli's life is a case in point. She displays her fortitude and self-reliance even at her old age. She does not want to relax or retire but to continue her work in the plantation, till health permits her: "Dorai asks 'Why do you still work? Why don't you ask your son to take care of you? She replies 'Why should I dorai? As long as I am able to work, no one needs to feed me. As long as god gives me strength I can feed four more people' (pp. 177-178). For Valli, nature is her companion and guide from which she draws strength and support. She considers the tea bush where her son Raman was buried, as her son himself. She consoles herself whenever she looks at the young and fresh green leaves: "She beat her chest and unable to quell the sorrow from her heart, she sobbed uncontrollably. As though sympathizing with the grieving mother, the bush shed its dewdrops like tears" (p. 121).

In the tea estate, life is so miserable that the refugees accept death as an ordinary event. In their wretched lives, where there is no room for humanity or compassion, they accept death as a gift from god. Valli has seen so many deaths in every stage of her refugee life. First, she 
loses her sister when her journey starts as a little girl. Secondly, she loses her mother; next she loses her unborn baby and her son Raman. Then, she loses her husband and her grandson, Mari. She is inconsolable and laments: "How many more have I to sacrifice before I die? You too have thrown dirt in my womb and have left me! You sinner!' sobbed Valli. The tea bushes flourish, bursting with vitality, having fed on the corpses of these hapless workers. Valli reviled them, 'You heartless monsters!'”(p. 197). Thus, in every situation, whether they are happy or sad, women always resort to nature.

In this novel, the women refugees encounter multilayered oppressions and discriminations. However, they tackle all these agonising challenges with profound determination and continue their arduous journey with incredible perseverance which they learn from Nature.

The women hung their baskets on their heads and walked up the hill in a single file. The air was filled with
gossip and laughter as they walked to their work-field. The tea bushes were adorned with sparkling dew and
the tender green leaves awaited the gentle touch of these women. The women too would get animated on
seeing a bush that had put out new leaves. The simple joys in their lives were thus enmeshed with the well-
being of these bushes.
(p. 97)

They strive hard ceaselessly for their family's betterment. But, their struggles and miseries remain hidden from the tea-consuming society all over the world. Hence, Subbiah poses this heart-rending question, "Those enjoying their daily cup of hot tea, how will they ever know the story behind this wonderful brew?" (p. 197). If the bushes could speak, they would tell a thousand tales about their trials and tribulations. Despite all the struggles in life, their indomitable spirit, their hope and desire for better life never die. As rightly perceived by Chakraborty "The debate on eco-feminism draws the perspective where women are not considered only as victims of development and environmental degradation; rather, they turn out to be leaders who hold the ability to overcome ecological crisis and work towards giving new meaning to life" (2018, p. 67).

\section{CONCLUSION}

While talking about the correlation between the environmental degradation and oppression of women in the hands of patriarchy, Sturgeon (2014) claims that "patriarchy equates women and nature, so that a feminist analysis is required to fully understand the genesis of environmental problems. In other words, where women are degraded, nature will be degraded, and where women are thought to be eternally giving and nurturing, nature will be thought of as endlessly fertile and exploitable" (p. 263). Also, most of the "ecofeminists attest to the interrelationship between the exploitation of nature and the degradation of women" (Abbasi \& Moslehi, 2016, pp. 18-19). Subbiah's Mirage provides ample proof for the victimisation and the resilience of women refugees and nature. Nature and women share the same traits and manifest similar action and reaction. They undergo the same kind of subjugation and exploitation, and maltreatment. The capitalists, who are the causative factors for environmental degradation and consequent disorders, again capitalise on the same and exploit the poor and the destitute. As a result, women and nature bear the brunt of human greed. In addition, as rightly studied by Warren, "naturalizing women" and "feminizing nature" render the socially and culturally dominant men more authority to exploit and victimise both women and nature. However, despite this massive destruction and exploitation, nature revives itself and human life as well. Similarly, women also, despite their multi-layered oppressions, rejuvenate themselves and their family with renewed hope. In every situation, women refugees strengthen and empower themselves from subjugation in order to lead harmonious lives. The metaphorical 
representation of nature proves that nature is a silent companion and guide to women where they can share their joys and sorrows. Women also obtain their potency from nature and this natural interlock with the environment provides them with the requisite determination and resilience to tackle life's challenges.

\section{REFERENCES}

Abbasi, P., \& Moslehi, M. (2016). Ecofeminism and Gilman's Herland: A Gaardian Approach. 3L: The Southeast Asian Journal of English Language Studies. Vol. 22(2), 17 - 29.

Ahmed, H Y., \& Hashim, R S. (2015). Greening of Resistance in Arabic Poetry: An Ecocritical Interpretation of Selected Arabic Poems. 3L: The Southeast Asian Journal of English Language Studies. Vol. 21(1), 13 22.

Ahmed, Mohammad K. (2019). "Ecofeminist Tendencies in Virginia Woolf, Doris Lessing and Arundhati Roy." International Journal of English, Literature and Social Science, Vol. 4, (4), 997-1002. https://dx.doi.org/10.22161/ijels.448

Alvi, A., Vengadasamy, R., \& Majid, Abdul, A B. (2019). The Philosophy of Nature In the Poetry of Ghulam Sarwar Yousuf and William Wordsworth: A Comparative Ecocritical Analysis. GEMA Online ${ }^{\circledR}$ Journal of Language Studies, Vol 19(4), 327-344. http://doi.org/10.17576/gema-2019-1904-17

Bates, D.C. (2002). Environmental Refugees? Classifying Human Migrations Caused by Environmental Change. Population and Environment, Vol. 23(5), 465-477.

Bruyn, Ben De. (2020). "The Great Displacement: Reading Migration Fiction at the End of the World." Humanities, Vol. 9(25), 1-16.

Chakraborty M. (2018). “An Eco-Feminist Water Revival Project in Gujarat.” Antyajaa: Indian Journal of Women and Social Change, Vol. 3(1), 64-81.

Gaard, G. (2015). Ecofeminism and Climate Change. Women's Studies International Forum, Vol. 49, 20-33.

Hooti, N., \& Ashrafian, A. (2014). D.H. Lawrence's St. Mawr: An Ecocritical Study. 3L: The Southeast Asian Journal of English Language Studies, Vol 20(2), 31-42. http://dx.doi.org/10.17576/3L-2014-2002-03

Kings, A.E. (2017). Intersectionality and the Changing Face of Ecofeminism. Ethics \& the Environment, Vol. 22 (1), 63-87.

King, Y. (1989). The Ecology of Feminism and the Feminism of Ecology. Healing The Wounds. Philadelphia: New Society.

Kurian, R., \& Jayawardena K. (2013, June 6-10). Plantation Patriarchy and Structural Violence: Women Workers in Sri Lanka. Legacy of Slavery and Indentured Labour. Conference on Bonded Labour, Migration, Diaspora and Identity Formation in Historical and Contemporary Context, Paramaribo, Suriname. http://repub.eur.nl/pub/50375/Metis_193809.pdf

Maretti, M., Tontodimamma, A., \& Biermann, P. (2019). Environmental and Climate Migrations: An Overview of Scientific Literature Using a Bibliometric Analysis. International Review of Sociology, Vol. 29(2), 142-158. DOI: 10.1080/03906701.2019.1641270.

Rathna P. (2020). Symbiosis of Women and Nature: An Ecofeministic Study of Indigenous Women in Doris Pilkington's Under the Wintamarra Tree. Forum for World Literature Studies, Vol. 12(3), 483-496.

Shiva, V. (2010). Staying Alive. Women, Ecology and Survival in India. Kali for Women. Women Unlimited: New Delhi.

Sturgeon, N. (2014). The Nature of Race: Discourse of Racial Difference in Ecofeminism. Ecofeminism: Women, Culture, Nature. Rawat Publications: New Delhi.

Subbiah, K. (2009). Mirage. Orient Black Swan, Publication. Chennai.

Sunani, K. C. (2017). Environmental Change and Migration: Policy Analysis in India. International Journal of Legal Developments and Allied Issues, Vol. 3(1), 15-34.

Tan, C. (2021). An Ecofeminist Interpretation of J.G. Ballard's The Drowned World. Turkish Academic Research Review, Vol. 6(1), 12-26.

Warren, K. J., \& Cady, Duane L. (1994). Feminism and Peace: Seeing Connections. Hypatia, Vol. 9(2), 4-20.

Warren, K. J. (2014). Taking Empirical Data Seriously: An Ecofeminist Philosophical Perspective. Ecofeminism. Women, Culture, Nature. Rawat Publications: New Delhi. 